\title{
PEMBINAAN KESEHATAN REMAJA DENGAN AKHLAK DAN BERBUDAYA SEHAT
}

\author{
Farida Ariyani ${ }^{1}$, Yulia Arifin ${ }^{2}$ \\ ${ }^{1}$ Program Studi DIII Kebidanan STIKes MERCUBAKTIJAYA Padang \\ 2Program Studi S1 Kebidanan STIKes MERCUBAKTIJAYA Padang \\ E-mail korespondensi: dzakwan.sayang@gmail.com
}

\begin{abstract}
Article History:
Received: 30 Maret 2021

Revised: 31 Maret 2021

Accepted: 27 April2021
\end{abstract}

Kata Kunci : Bina Remaja, Reproduksi Remaja, Budaya

Keywords: youth development, adolescent reproduction, culture

\begin{abstract}
Abstrak:
Latar Belakang : Korong Palembayan merupakan daerah yang masih melekat sifat kedaerahan dan budaya yang masih menjadi tradisi. Walaupun ada beberapa masyarakat sudah mengalami modernisasi dalam pola kehidupannya. Perobahan zaman juga membawa dampak pergeseran pola kehidupan remaja di korong Palembayan. Kemajuan teknologi juga dirasakan dan dimanfaatkan oleh remaja daerah tersebut. Namun kemampuan remaja dalam menyaring dan menganalisa informasi yang didapat belum lagi optimal. Korong Palembayan masih mencatat pernikahan perempuan diusia remaja. Bahkan mereka yang menikah diusia remaja merupakan perempuan yang tidak dapat melanjutkan pendidikan kejenjang yang lebih tinggi.
\end{abstract}

Metode : Pengabdian masyarakat ini dilakukan di Korong Palembayan, Nagari Sintuk Kecamatan Sintuk Toboh gadang dengan mekanisme pelaksanaan kegiatan ini dilakukan dengan mengadopsi langkah-langkah action research yang terdiri dari perencanaan, tindakan, observasi dan evaluasi, refleksi. Kegiatan ini dilakukan pada Tanggal 22 september 2019 di Kantor balai pertemuan (TK) Korong Palembayan.

Hasil: untuk media atau wadah peningkatan pengetahuan dan informasi mengenai kegiatan spiritual maka kegiatan yang dilakukan dalam bentuk wirid remaja. Selain itu sudah dibangun laga-laga sebagai tempat untuk mengembangkan dan menampung potensi remaja dalam hal kebudayaan. Mereka bisa melakukan kesenian beladiri alo-ambek dan tambua untuk pengembangan kesenian dan budaya daerah. Kelompok remaja dikorong Palembayan juga memiliki grup media sosial untuk berbagi ilmu dan informasi tentang kesehatan remaja serta kegiatan-kegiatan yang akan dilakukan bagi remaja tersebut.

\section{Abstract:}

Background: Korong Palembayan is an area that is still attached to regional and cultural characteristics that are still a tradition. Although there are several societies that have experienced modernization in their life patterns. Changes in the times have also had an impact on shifting patterns of youth life in Korong Palembayan. The youth of the area have also felt and used technological advances. However, the ability of adolescents to filter and analyze the information obtained is not yet optimal. Korong Palembayan still records the marriage of women in their teens. Even those who get married when they are teenagers are women who cannot continue their education to a higher level. 


\begin{abstract}
Method: This community service is carried out in Korong Palembayan, Nagari Sintuk, Sintuk Toboh Gadang District. The mechanism for implementing this activity is carried out by adopting action research steps consisting of planning, action, observation and evaluation, reflection. This activity was carried out on 22 September 2019 at the Wali Korong Palembayan Office.

Result: The forum or media used by teenagers for spiritual activities is teenage wirid. Wirid help adolescents to increase their understanding of religion and worship. In addition, in Palembayan already built of Laga-laga. They can do aloambek and tambua martial arts for the development of regional arts and culture. Palembayan youth groups to also have social media groups to share knowledge and information about adolescent health and activities that will be carried out for these adolescents.
\end{abstract}

\title{
Pendahuluan
}

Usia remaja merupakan masa yang suka berinteraksi dan berdiskusi dengan orang lain atau teman sebayanya, mereka akan mencari informasi apapun yang memancing keingintahuan mereka. Media dan informasi yang salah yang diterima oleh remaja akan berdampak pada perilaku remaja yang akan datang, untuk itu perlu disediakan wadah dan media bagi remaja untuk belajar memahami dan menganalisa informasi yang didapatnya (Herlina, 2013).

Remaja diberikan wadah untuk berdiskusi sesama teman sebayanya dengan berbagi informasi yang baik dan benar terutama kesehatan reproduksi, dan melakukan kegiatan yang positif dalam mengisi waktu luang. Bentuk kegiatan pembinaan remaja ini dengan membentuk kelompok bina teman sebaya. Pembinaan yang lebih khusus diarahkan pada kesehatan reproduksi (Putro, 2017). Korong Palembayan berada dalam wilayah nagari Sintuk, Kecamatan Sintuk Toboh Gadang, Kabupaten Padang Pariaman. Korong Palembayan merupakan daerah yang masih melekat sifat kedaerahannya. Sebagian besar masyarakatnya masih menjalankan tradisi warisan budaya di daerahnya, walaupun ada beberapa masyarakat sudah mengalami modernisasi dalam pola kehidupannya.

Perubahan zaman juga membawa dampak pergeseran pola kehidupan remaja di Korong Palembayan. Kemajuan teknologi juga dirasakan dan dimanfaatkan oleh remaja daerah tersebut, namun kemampuan remaja dalam menyaring dan menganalisa informasi yang didapat belum lagi optimal. Remaja yang tumbuh dalam lingkungan keluarga yang kurang komunikatif antara orang tua dan remaja akan mengalami masalah dalam menyerap informasi (Jannah, 2016). Informasi dari masyarakat menyampaikan bahwa di Korong Palembayan perempuan menikah diusia remaja. Sekitar 7,5\% perempuan yang menikah diusia remaja merupakan perempuan yang tidak dapat melanjutkan pendidikan kejenjang yang lebih tinggi.

Untuk itu pendidikan dan pembinaan remaja di Korong Palembayan perlu dilakukan. Hal ini berkaitan dengan pencegahan perempuan menikah, hamil, melahirkan bahkan nifas pada usia muda yang rentan pada resiko tinggi dalam tugas 


\section{Jurnal ABDI MERCUSUAR}

dan fungsi reproduksinya. Menikah pada usia muda juga menimbulkan masalah pada pelaksanaan fungsi dan peran perempuan yang rendah dimasyarakat, karena tingkat pendidikan yang rendah yang kurang memiliki pengetahuan dalam melaksankan kehidupan. Agar generasi penerus yang dilahirkan sehat dan berkualitas maka perlu dilakukan pembinaan pada remaja di Korong Palembayan ini.

Untuk mencapai remaja yang sehat dan berkualitas tersebut maka pengabdian masyarakat ini perlu dilakukan. Remaja diberikan wadah untuk berdiskusi sesama teman sebayanya dengan berbagi informasi yang baik dan benar terutama kesehatan reproduksi, dan melakukan kegiatan yang positif dalam mengisi waktu luang.

\section{Metode Pelaksanaan}

Rancangan mekanisme pelaksanaan kegiatan ini dilakukan dengan mengadopsi langkah-langkah action research yang terdiri dari 4 (empat) tahap, yaitu Perencanaan, tindakan, observasi, dan evaluasi serta refleksi.

1. Tahap Perencanaan

a. Survey awal dengan mewawancarai beberapa remaja, dan masyarakat serta wali Korong Palembayan tentang kondisi remaja di palembayan

b. Mengkoordinasikan hasil survey dengan Bidan penanggung jawab korong Palembayan

c. Koordinasi dan konfirmasi pelaksanaan kegiatan dengan penanggung jawab program PKPR Puskesmas Sintuk.

2. Tahap Pelaksanaan

a. Mengumpulkan remaja di Balai Pertemuan (TK Korong Palembayan), memberikan pendidikan kesehatan mengenai kesehatan reproduksi remaja dan pengenalan Program Kesehatan Peduli Remaja (PKPR) bersama perangkat Korong Palembayan yang dihadiri juga oleh Bidan Korong Palembayan.

b. Diskusi Pembentukan Organisasi remaja Korong Palembayan
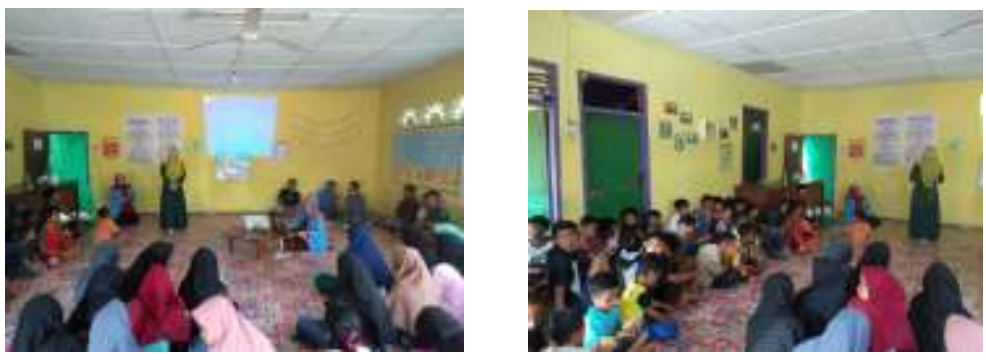

Gambar. 1

Pertemuan dengan remaja, pemuka masyarakat dan Bidan Korong

3. Tahap Observasi

Antusias remaja dalam mengikuti kegiatan pembinaan remaja cukup besar. Remaja membentuk organisasi dan mendiskusikan rancangan kegiatan organisasi.

4. Tahap evaluasi

Pembinaan pengelola atau pengurus organisasi perlu dibenahi dan dilanjutkan 


\section{Jurnal ABDI MERCUSUAR}

intervensinya. Mengenai keberlanjutan tersebut, penanggung jawab PKPR Puskesmas Sintuk dan bidan Korong Palembayan sudah menyampaikan kesediaannya untuk melakukan pembinaan lebih lanjut.

\section{Hasil}

Kegiatan pembinaan remaja Korong Palembayan tersebut dapat dijabarkan sebagai berikut, perencanaan pembentukan organiasi PKPR remaja Palembayan bekerja sama dengan bidan pembina wilayah yang akan ditindak lanjuti ke Puskesmas Sintuk untuk koordinasi pembentukan dan pengelolaan organisasi. Pada pertemuan tersebut dilakukan penyuluhan tentang Reproduksi Sehat Bagi Remaja, Organisasi remaja Dan PKPR yang dilakukan pada tanggal 22 September 2019. Pendidikan dan penyampaian materi dilakukan oleh Tim Pengabdi dari STIKes MERCUBAKTIJAYA Padang (dosen dan mahasiswa), dan juga kepala bidang pembinaan masyarakat nagari Sintuk (Bapak Radhelka Azki).

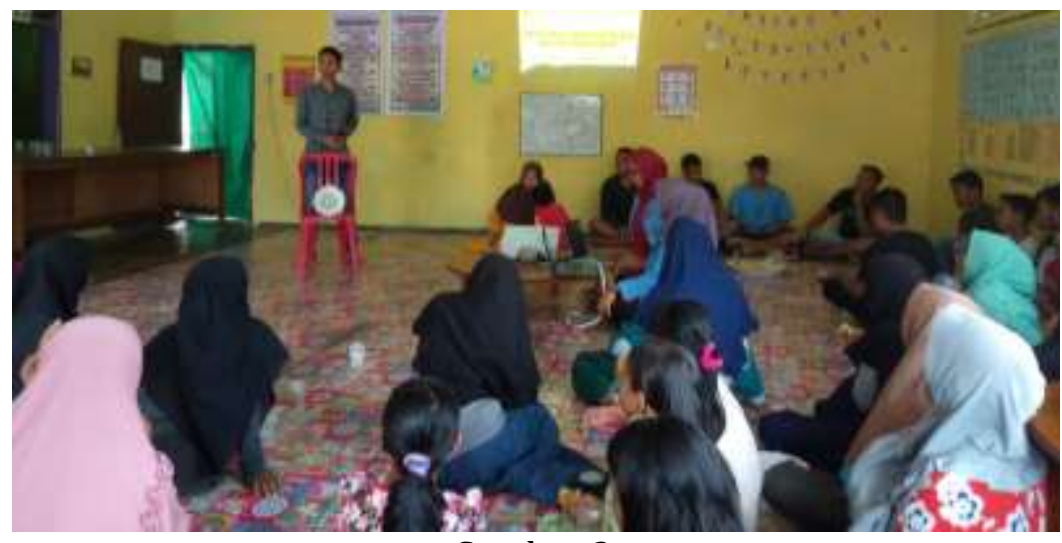

Gambar 2.

Kepala Bidang Pembinaan Masyarakat Nagari Sintuk (Bapak Radhelka Azki)

Langkah pertama yang dilakukan oleh organisasi remaja tersebut adalah membentuk forum komunikasi melalui grup sosial media. Melalui media grup tersebut disampaikan informasi rencana rapat atau diskusi berkala seluruh remaja yang tergabung dalam organisasi remaja tersebut. Diskusi berkala dilakukan dengan pertemuan langsung remaja yang dihadiri oleh tokoh masyarakat ataupun perangkat pimpinan Korong Palembayan.

Remaja Palembayan sudah memiliki alat seni "tambua" yang merupakan seni warisan budaya minangkabau, yang dapat diasah dan dikembangkan sebagai bentuk program kegiatan remaja yang berakhlak. Melalui kegiatan seni budaya, juga dapat meminimalkan aktifitas yang dapat memberi pengaruh negative pada remaja. Dengan kegiatan seni budaya maka remaja akan lebih menghargai positifnya budaya dan seni untuk kehidupan dimasa yang akan datang, dan dapat memperkenalkan daerahnya ke daerah luar Palembayan. Selain itu, kegiatan keagamaan yang direncanakan adalah dengan mengaktifkan wirid remaja yang dilaksankan 2 kali dalam satu bulan.

Dengan adanya wadah dan kegiatan remaja ini, maka diharapkan dampak yang baik akan dirasakan oleh remaja khususnya dan seluruh masyarakat Korong Palembayan pada umumnya. Dengan demikian harapan bahwa remaja Palembayan 


\section{Jurnal ABDI MERCUSUAR}

lebih memiliki pola fikir dan tingkat pendidikan dan pengetahuan lebih tinggi akan kesehatan. Pernikahan usia muda dapat diminimalisir dengan semakin tingginya derajat pendidikan dan pengetahuan secara umum.

\section{Diskusi}

Perkembangan remaja membutuhkan pengontrolan oleh orang tua dan masyarakat, namun sifat remaja yang cendrung lebih percaya terhadap teman sebaya menempatkan remaja itu pada kondisi dilema. Untuk itu perlu membina beberapa remaja yang memiliki prilaku dan kegiatan positif untuk dapat mendukung dan membantu teman sebayanya keluar dari ketidakstabilan emosi dan prilakunya. Demikian juga dengan remaja di Korong palembayan. Kemajuan teknologi yang dimanfaatkan oleh remaja tapi tidak dipahami oleh orangtua pada umumnya.

Seperti halnya pemerintah yang bertindak dengan melahirkan program Pelayanan Kesehatan Peduli Remaja. Dimana program ini bertujuan untuk memberikan pembinaan dan pelayanan kesehatan remaja dengan mengembangkan kemampuan teman sebayanya memberikan pelayanan kesehatan dan konseling sebaya. Pembinaan dilakukan kepada remaja yang memiliki potensi dalam melayani dan memberikan solusi atas permasalahan teman sebayanya. Program ini juga melakukan penyediaan wadah atau organisasi bagi remaja itu sendiri dalam pengkoordinasian dan evaluasi kegiatan. Sehingga, program ini merupakan media besar dalam pengentasan permasalahan remaja dan kesehatan reproduksi (Dirjen Bina Gizi dan KIA, 2014).

Selain pembinaan remaja dalam hal pelayanan kesehatan dan konseling oleh teman sebaya, organisasi remaja telah bergerak melaksanakan kegiatan keagamaan dan kebudayaan. Pelaksanaan kegiatan keagamaan memberikan dampak peningkatan iman bagi remaja dan kontrol internal dari perkembangan emosional yang labil bagi remaja itu sendiri. Peningkatan pemahaman akan ajaran agama dan tugas perkembangannya secara islami akan menekan emosional yang negatif bagi tugas perkembangannya. Demikian juga peningkatan partisipatif dalam kegiatan kebudayaan, dimana kegiatan kebudayaan memberikan nilai positif kehidupan bersosial dan bermasayakat. Dengan mengikuti dan berpartisipasi aktif dalam kegiatan kebudayaan meningkatkan potensi remaja dalam mengembangkan kebudayaan daerahnya.

Berbeda halnya dengan remaja yang terpengaruh oleh teknologi dan media yang memiliki gaya hidup mengikuti idolanya. Seperti remaja pecinta grup musik remaja luar negeri. Tren luar negeri memberikan pengaruh nilai sosial yang cenderung bertolak belakang dengan kebudayaan daerah Minangkabau. Oleh sebab itu pengaktifan kegiatan kebudayaan tradisional akan mengurangi dampak kurang baik terhadap prilaku remaja kita. seperti halnya penelitian yang dilakukan oleh Olivia M. Kaparang yang mengatakan bahwa remaja cenderung mengimitasi idolanya dalam berprilaku. Semakin kuat remaja mengidolakan seseorang atau sesuatu maka akan semakin tajam imitasi prilaku remaja tersebut (Kaparang, 2013). Oleh sebab itu remaja harus diarahkan dan dibina dalam memenuhi tugas perkembangannya. 


\section{Kesimpulan dan Saran}

Pembentukan organisasi dan sosialisasi kegiatan pembinaan remaja melalui organisasi remaja merupakan solusi yang cukup baik untuk masa depan remaja. Melalui wadah ini remaja merancang kegiatan dan akifitas yang dilakukan diluar kegiatan belajar atau sekolah yang dijalani. Kegiatan tersebut dikoordinir oleh pemuka masyarakat dan puskesmas.

\section{Ucapan Terima Kasih}

Penulis mengucapkan terimakasih kepada ketua Yayasan MERCUBAKTIJAYA Padang yang telah memberikan dukungan moril dan materil untuk terlaksananya kegiatan pengabdian masyarakat ini. Dan terima kasih kepada Wali Korong Palembayan Nagari Sintuk atas izin pelaksanaan pengabdian masyarakat dan dukungan dan kerjasamanya dalam terlaksananya kegiatan pembinaan remaja ini. Serta semua pihak yang membantu lancarnya kegiatan pembentukan organisasi dan pembinaan remaja ini.

\section{Daftar Referensi}

Dirjen Bina Gizi dan KIA. (2014). Pedoman Standar Nasional PKPR. Jakarta: Kementrian Kesehatan RI.

Herlina. (2013). bibliotherapy: Mengatasi Masalah Anak dan Remaja melalui Buku. Bandung: Pustaka Cendikia Utama.

Jannah, M. (2016). Remaja dan Tugas Perkembangannya dalam Islam. Jurnal Psikoislamedia, 1(April), 243-256.

Putro, K. Z. (2017). Memahami Ciri dan Tugas Perkembangan Masa Remaja. 17, $25-32$. 